\title{
Morphological Studies on the Indonesian Native Chicken
}

\author{
Takao Nishida, Yoshihiro Hayashi, Ken Nozawa ${ }^{*}$, Tsutomu \\ HASHIGUCHI $^{* *}$ and Sri Supraptini MANSJOER ${ }^{* * *}$ \\ Laboratory of Veterinary Anatomy, Faculty of Agriculture, \\ University of Tokyo, Bunkyo-ku, Tokyo 113 \\ * Department of Variation Research, Primate Research Institute, \\ Kyoto University, Inuyama-shi, 484 \\ ** Laboratory of Animal Breeding, Faculty of Agriculture, \\ Kagoshima University, Kagoshima-shi 890 \\ *** Laboratory of Animal Breeding and Genetics, Faculty \\ of Animal Science, Bogor Agriculture \\ University, Bogor, Indonesia
}

(Received April 15, 1988)

\begin{abstract}
In investigations of the Indonesian native livestock in 1977, 1978 and 1981, a total of 212 native chickens consisting of 164 males and 48 females, was measured for 8 different body parts and their body weights. The principal component analysis was applied to the discrimination of this body measurement. Results of the principal component analysis indicate that: 1) There were no clear differences in the body size and shape between 8 chicken populations in Indonesia except the game type. 2) The game type of the male Madura and the same type of the male South Sulawesian called Bangkok composed the largest group in size, based on the discrimination afforded by the size vector (PC 1). Some external genetic characters of 5,845 native chickens were recorded at 11 provinces in Indonesia. From the results obtained, the following values were calculated: The frequencies (q) of genes controlling these morphological characters, the admixture (Q) of European breeds, the native gene content in the present-day native chicken population and the frequencies in the native chicken population not attributable to the inflow from European breeds $\left(\mathrm{q}^{(\mathrm{N})}\right)$. These results indicate that the Indonesian native chicken holds about $50 \%$ native genes on the average.
\end{abstract}

Jpn. J. Zootech. Sci., 59 (12) : 1047-1058, 1988

Key words : Indonesia, native chicken, body measurement, external character

Although few morphological studies have been found on the analysis of differentiation of the chicken breeds, the craniometry ${ }^{13}$ and the body measurement ${ }^{2-5)}$ were recently applied to the morphological analysis. The senior author and his colleagues have carried out the body measurement and the analysis of morphological genetic characters for the different chicken populations in Southeast $\mathrm{Asia}^{3-7}$. Concerning the breeds of native chicken in Indonesia, there have been no accurate literatures, but the Statistical Pocketbook of Indonesia ${ }^{8)}$ published in 1977 describes that the Indonesian poultry is still mainly composed of indigenous breeds (96.4\%), 
called "Aym Kampong" in Indonesia. Of these Indonesian native chickens, the Aym Kedu in West Jawa is characterized by the black-colored feather, and the Ayam Mutioar in East Kalimantan possesses the pearl colored feather consisting of white, gray and black feathers characteristic in the Indonesian local breeds, but they have a short history counting only less than 50 years.

In the 1977, 1978 and 1981 investigations for the Indonesian native livestock, the body conformation, gene constitution and native gene content of the Indonesian native chicken population were estimated by means of the body measurements and the recording of the external genetic characters.

\section{Materials and Methods}

During the 1977, 1978 and 1981 surveys in Indonesia, the body measurement was performed for 164 male and 48 female native chickens by the methods of BALL ${ }^{9}$, BALDwin et $a .^{10)}$ and NisHIDA et al. ${ }^{2)}$, using a slide gauge fitted with a vernier scale. Eight different body parts were measured, i.e., the length of femur, tibia, tarsometatarsus, third digit, wing and maxilla, the circumference of tarsometatarsus and the height of comb. The body weight was also measured with a spring balance. Results from the body measurement of Indonesian native chickens are given in Table 1 and 2. Table 3 and Fig. 1 indicate results of the principal component analysis applied to the discrimination of their body conformation.

The morphological genetic character - feather color (I-, ii, S-, ss), plumage

Table 1. Body weight and measurement

\begin{tabular}{|c|c|c|c|c|c|c|}
\hline \multirow[b]{2}{*}{ Locality } & \multirow[b]{2}{*}{ Sex } & \multirow[b]{2}{*}{ No } & \multicolumn{3}{|c|}{ Length of long bone } & \multirow[b]{2}{*}{$\begin{array}{c}\text { Combined } \\
\text { length }\end{array}$} \\
\hline & & & Fermur & Tibia & $\begin{array}{l}\text { Tarsome- } \\
\text { tatarsus } \\
\text { (t. m.t.) }\end{array}$ & \\
\hline \multirow{2}{*}{ Aceh } & M & 10 & 91.0 & 139.2 & 99.9 & 330.0 \\
\hline & $\mathrm{F}$ & 11 & 85.7 & 125.8 & 86.5 & 298.0 \\
\hline \multirow{2}{*}{$\begin{array}{l}\text { Sumatra } \\
\text { Barat }\end{array}$} & M & 3 & 93.5 & 149.2 & 98.4 & 341.0 \\
\hline & $\mathrm{F}$ & 14 & 82.9 & 123.3 & 82.4 & 288.6 \\
\hline \multirow{2}{*}{$\begin{array}{l}\text { Sumatra } \\
\text { Utara }\end{array}$} & M & 5 & 96.5 & 153.3 & 105.5 & 355.4 \\
\hline & $\mathrm{F}$ & 15 & 86.1 & 123.6 & 86.1 & 295.8 \\
\hline \multirow{2}{*}{$\begin{array}{l}\text { Madura } \\
\text { type } 1\end{array}$} & M & 3 & 95.1 & 154.3 & 100.1 & 349.6 \\
\hline & $\mathrm{F}$ & 9 & 91.1 & 140.0 & 93.4 & 324.6 \\
\hline \multirow{2}{*}{$\begin{array}{l}\text { Madura } \\
\text { type } 2\end{array}$} & $\mathrm{M}^{*}$ & 2 & 106.6 & 170.3 & 118.2 & 395.0 \\
\hline & $\mathrm{F}^{*}$ & 9 & 96.1 & 144.9 & 98.9 & 339.9 \\
\hline \multirow{2}{*}{ Bali } & M & 6 & 95.9 & 144.9 & 99.5 & 340.3 \\
\hline & $F$ & 56 & 85.7 & 126.6 & 84.5 & 296.9 \\
\hline \multirow{2}{*}{ Sumbawa } & M & 5 & 993 & 159.5 & 111.0 & 370.8 \\
\hline & $F$ & 19 & 87.0 & 132.8 & 90.5 & 310.3 \\
\hline Sulawesi & $\mathrm{M}^{*}$ & 14 & 131.5 & 163.7 & 115.2 & 410.3 \\
\hline Selatan & $\mathrm{F}$ & 31 & 95.5 & 134.6 & 91.4 & 321.5 \\
\hline
\end{tabular}

*Game 
pattern $\left(\mathrm{E}^{-}-\mathrm{e}^{+}-\right.$, ee, $\left.\mathrm{B}^{-}, \mathrm{bb}\right)$, shank color (Id-, idid) and comb shape $(\mathrm{P}-$-, pp) - were recorded for native chickens. The number of chicken recorded was 3,159 in Jawa, Madura, Bali and Lombok in 1977, 2,352 in Aceh, West Sumatra, West Jawa, Madura, South Sulawesi, Bali, Lombok and Sumabawa in 1978, and 334 in South Sulawesi, North Sumatra and Bali in 1981. The results obtained from the trials described above were used for the calculations of the overall frequencies (q) of genes controlling these morphological characters, the admixture $(Q)$ of European improved breeds introduced into Asian countries including Indonesia, and frequencies in the native chicken population not attributable to the inflow from European improved breeds $\left(\mathrm{q}^{(\mathrm{N})}\right)$. The native gene content in the present-day native chicken population in Indonesia was also estimated. The analytical methods and formulas used for these calculations were described in the preceding report of this series ${ }^{3)}$.

\section{Results}

1. Body measurement of Indonesian native chickens

Results from the body measurement of 164 male and 48 female native chickens including the game type are shown in Table 1, and also the Indonesian native chicken is compared with the Philippine ${ }^{5)}$ and Malaysian ${ }^{2)}$ in Table 2.

The principal component analysis was carried out using the mean values of 8 variables of body measurement. The first principal component (PC 1) accounted for $80.6 \%$ of all the variations and the second component (PC 2) for $10.7 \%$ (Table 3),

of Indonesian native chicken (mean, $\mathrm{g}, \mathrm{mm}$ )

\begin{tabular}{lllllrl}
\hline \hline $\begin{array}{c}\text { Circum- } \\
\text { ference } \\
\text { of t. m. t. }\end{array}$ & $\begin{array}{l}\text { Lemgth } \\
\text { of tmt }\end{array}$ & $\begin{array}{c}\text { Length } \\
\text { of 3rd } \\
\text { digit }\end{array}$ & $\begin{array}{c}\text { Length } \\
\text { of } \\
\text { wing } \\
\text { tmt }\end{array}$ & $\begin{array}{c}\text { Length } \\
\text { of } \\
\text { maxilla }\end{array}$ & $\begin{array}{c}\text { Height } \\
\text { of } \\
\text { comb }\end{array}$ & $\begin{array}{c}\text { Body } \\
\text { weight }\end{array}$ \\
\hline 38.3 & 2.700 & 71.3 & 212.7 & 62.3 & 20.4 & $1,490.0$ \\
32.6 & 2.657 & 65.4 & 195.7 & 59.2 & 8.1 & $1,231.8$ \\
39.0 & 2.548 & 75.5 & 224.0 & 64.1 & 23.9 & $1,433.3$ \\
36.6 & 2.263 & 65.2 & 192.0 & 61.5 & 11.6 & $1,171.4$ \\
44.8 & 2.358 & 74.1 & 217.0 & 67.7 & 27.0 & $1,872.0$ \\
37.3 & 2.309 & 63.5 & 200.9 & 62.0 & 16.0 & $1,377.3$ \\
40.3 & 2.481 & 74.9 & 202.7 & 65.8 & 16.5 & $1,633.3$ \\
39.3 & 2.328 & 72.0 & 188.0 & 64.0 & 9.5 & $1,555.6$ \\
53.5 & 2.208 & 88.7 & 224.0 & 73.4 & 44.3 & $2,600.0$ \\
42.7 & 2.328 & 72.5 & 195.9 & 65.4 & 12.6 & $2,200.0$ \\
42.3 & 2.349 & 68.3 & 222.1 & 66.2 & 43.1 & $1,490.0$ \\
36.8 & 2.296 & 62.0 & 201.2 & 61.4 & 17.4 & $1,263.9$ \\
45.6 & 2.466 & 76.4 & 221.0 & 68.5 & 23.7 & $2,140.0$ \\
36.0 & 2.517 & 67.9 & 198.8 & 61.5 & 10.8 & $1,500.0$ \\
46.2 & 2.491 & 78.0 & 223.3 & 71.6 & 27.7 & $2,117.9$ \\
37.8 & 2.419 & 69.1 & 197.2 & 63.0 & 13.0 & $1,517.8$ \\
\hline
\end{tabular}


Nishida, Hayashi, Nozawa, Hashiguchi and Mansjogr

Table 2. Comparison of body weight and measurement of Indonesian,

\begin{tabular}{|c|c|c|c|c|c|}
\hline \multirow{3}{*}{\multicolumn{2}{|c|}{$\begin{array}{l}\text { Type of body formation } \\
\text { Sex }\end{array}$}} & \multirow{2}{*}{\multicolumn{2}{|c|}{$\begin{array}{l}\text { Indonesian* } \\
\text { native fowl }\end{array}$}} & \multirow{2}{*}{\multicolumn{2}{|c|}{$\begin{array}{l}\text { Philippine } \\
\text { Game }\end{array}$}} \\
\hline & & & & & \\
\hline & & Male & Female & Male & Female \\
\hline & 32 & 124 & 11 & 2 \\
\hline \multicolumn{2}{|c|}{ Body weight } & $1,676.4$ & $1,350.0$ & $1,968.2$ & $1,600.0$ \\
\hline \multirow{4}{*}{$\begin{array}{l}\text { Length of } \\
\text { long bone }\end{array}$} & Femur & 95.2 & 86.4 & 90.4 & 84.9 \\
\hline & Tibia & 150.1 & 128.7 & 136.2 & 126.4 \\
\hline & Tarsometatarsus & 102.6 & 87.3 & 97.2 & 82.3 \\
\hline & Combined length & 349.9 & 302.4 & 323.8 & 293.6 \\
\hline \multicolumn{2}{|c|}{$\begin{array}{l}\text { Circumference of } \\
\text { tarsometatarsus }\end{array}$} & 41.7 & 36.5 & 40.3 & 38.0 \\
\hline \multirow{2}{*}{\multicolumn{2}{|c|}{$\frac{\text { Length of } t . \mathrm{m} . \mathrm{t} .}{\text { Circumference of } t . \mathrm{m} t}$}} & 2.484 & 2.395 & 2.431 & 2.177 \\
\hline & & 2.404 & 2.050 & 2.701 & \\
\hline $\begin{array}{l}\text { Circumference of } t . \mathrm{m} . \mathrm{t} \\
\text { Length of } 3 \text { rd digit }\end{array}$ & d digit & 73.4 & 66.0 & 77.6 & 73. 4 \\
\hline \multicolumn{2}{|c|}{ Length of wing } & 216.6 & 196.1 & 246.2 & 210.0 \\
\hline \multicolumn{2}{|c|}{ Length of maxilla } & 65.8 & 61.6 & 69.2 & 63.6 \\
\hline \multicolumn{2}{|c|}{ Height of comb } & 25.8 & 12.2 & 56.1 & 27.8 \\
\hline
\end{tabular}

* mean values of those of 6 populations except game type asterisked in Table 1.

Table 3. Eigenvectors of the first and second principal components

\begin{tabular}{lcc}
\hline $\begin{array}{l}\text { Variables of } \\
\text { body } \\
\text { measurement }\end{array}$ & $\begin{array}{c}\text { Component 1 } \\
(80.6 \%)\end{array}$ & $\begin{array}{c}\text { Component } 2 \\
(10.7 \%)^{*}\end{array}$ \\
\hline Length of long bone & 0.365 & -0.423 \\
Femur & 0.544 & -0.302 \\
Tibia & 0.408 & -0.044 \\
Tarsometatarsus & 0.178 & -0.044 \\
Circumference of & 0.224 & -0.172 \\
tarsometatarsus & 0.429 & 0.577 \\
Length of 3rd digit & 0.142 & -0.068 \\
Length of wing & 0.345 & 0.575 \\
Length of maxilla & Height of comb &
\end{tabular}

* The percentage accounted for total variations by the component

indicating that the sum of the components reached no less than $90 \%$. In the morphometric applications of this analysis, the PC 1 was acceptable as a "size" vector, and the PC 2 as a "shape" vector".

As shown in Table 3, the eigenvectors in PC 1 were 0.544 for the tibia, 0.429 for the wing, 0.408 for the tarsometatarsus and 0.365 for the femur length, and 0.345 for the height of comb, indicating that these 5 variables contributed to the discrimination of the body size. Of the eigenvectors in $\mathrm{PC} 2$, the four variables were adopted for the discrimination of the shape : 0.577 and 0.575 for the length of wing and the height of comb, respectively, as a positive-value group, and -0.423 and -0.302 for the length of femur and tibia, respectively, as a negative-value group. 
Morphology of Indonesian Native Chicken

Philippine and Malaysian native chicken ( $\mathrm{g}, \mathrm{mm}$, mean)

\begin{tabular}{|c|c|c|c|c|c|}
\hline \multirow{2}{*}{\multicolumn{2}{|c|}{$\frac{\text { native fowl }}{\text { Non-game }}$}} & \multicolumn{4}{|c|}{ Malaysian native fow 1} \\
\hline & & \multicolumn{2}{|c|}{ Game } & \multicolumn{2}{|c|}{ Non-game } \\
\hline Male & Female & Male & Female & Male & Female \\
\hline 8 & 23 & 17 & 11 & 3 & 24 \\
\hline $1,218.8$ & $1,111.3$ & $2,576.5$ & $1,636.4$ & $1,366.7$ & $1,384.2$ \\
\hline 83.0 & 79.6 & 108.4 & 86.7 & 88.4 & 83.0 \\
\hline 125.9 & 114.6 & 154.8 & 122.1 & 122.8 & 112.8 \\
\hline 89.6 & 81.4 & 114.7 & 85.0 & 97.6 & 80.6 \\
\hline 298. & 275.6 & 377.9 & 293.8 & 308.9 & 279.5 \\
\hline 37.3 & 31.8 & 50.4 & 37.3 & 44.3 & 35.7 \\
\hline 2.424 & 2.585 & 2.285 & 2.285 & 2. 199 & 2.279 \\
\hline 72.0 & 67.9 & 83.8 & 66.9 & 70.9 & 65.5 \\
\hline 202.8 & 188.8 & 238.1 & 185.9 & 183.3 & 189.1 \\
\hline 60.5 & 58.7 & 72.0 & 63.6 & 61.3 & 61.9 \\
\hline 27.3 & 14.3 & 21.9 & 9.4 & 34.4 & 15.5 \\
\hline
\end{tabular}

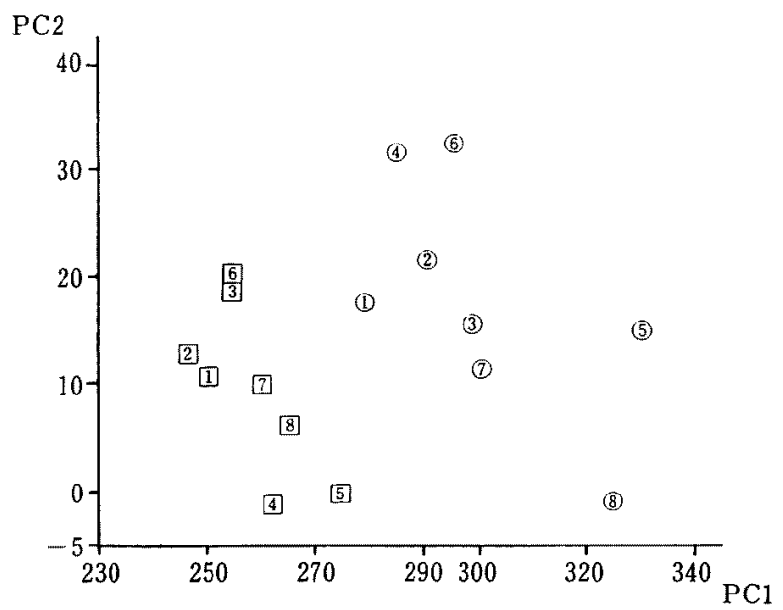

Fig. 1. Principal component chart of the first two transformed variables from 8 variables of body measurement for Indonesian native fowls. $\bigcirc$ male; $\square$ female; 1 , Aceh; 2, Sumatra Barat; 3 , Sumatra Utara; 4, Madura; 5, Madura (game); 6, Bali ; 7, Sumbawa; 8 , Sulawesi Seratan.

The principal component chart shown in Fig. 1 indicates that: 1) The game type of the male Madura and the same type of the male South Sulawesian called Bangkok composed the largest group in size, based on the discrimination afforded by the size vector (PC 1): 2) There was a clear sexual dimorphism in the body size and shape in all of 8 native chicken populations. The largest sexual difference in shape was observed in the Madura native chicken, and the smallest difference in Sumbawa; 3 ) 
Nishida, Hayashi, Nozawa, Hashiguchi and Mansjogr

There were no clear differences in the body size and shape between 8 chicken populations in Indonesia except the game type asterisked in Table 1.

2. Analysis of morphological genetic characters of Indonesian native chickens

Table 4. Comparison of gene frequencies in Indonesia, Philippine, Thai and Malaysian native chichen (1977 and 1978)

\begin{tabular}{|c|c|c|c|c|c|c|c|c|}
\hline $\begin{array}{l}\text { Gene } \\
\text { frequency }\end{array}$ & $\mathrm{q}_{\mathrm{s}}$ & $\mathrm{q}_{\mathrm{E}}$ & $\mathrm{qe}_{\mathrm{e}}+$ & $\mathrm{q}_{e}$ & qs & $\mathrm{qB}_{\mathrm{B}}$ & $\mathrm{q}_{\mathrm{Id}}$ & $q_{P}$ \\
\hline \multicolumn{9}{|l|}{$\begin{array}{l}\text { Indonesia } \\
\text { Investigation in } \\
1977\end{array}$} \\
\hline Jawa Timur & 0.0623 & 0.2482 & 0.3371 & 0.4147 & 0.0627 & 0.0143 & 0.7179 & 0.6101 \\
\hline Jawa Tengah & 0.0487 & 0.2162 & 0.3330 & 0.4508 & 0.0914 & 0.0092 & 0.6269 & 0.6565 \\
\hline Jawa Barat & 0.0312 & 0.3162 & 0.3176 & 0.3662 & 0.1451 & 0.0030 & 0.5399 & 0.7025 \\
\hline Madura & 0.0525 & 0.2748 & 0.3665 & 0.3587 & 0.1022 & 0.0149 & 0.5530 & 0.5559 \\
\hline Bali & 0.1025 & 0.1572 & 0.4033 & 0.4395 & 0.2802 & 0.0240 & 0.4473 & 0.1522 \\
\hline Lombok & 0.0871 & 0.1102 & 0.5671 & 0.3227 & 0.2894 & 0.0847 & 0.4640 & 0.0808 \\
\hline \multicolumn{9}{|l|}{$\begin{array}{l}\text { Investigation in } \\
1978\end{array}$} \\
\hline Aceh & 0.0239 & 0.1112 & 0.3571 & 0.5317 & 0.1568 & 0.0165 & 0.5841 & 0.5250 \\
\hline Sumatra Barat & $0.022 \nexists$ & 0.1336 & 0.3454 & 0.5210 & 0.1445 & 0.0495 & 0.5884 & 0.3381 \\
\hline Jawa Barat & 0.0126 & 0.2156 & 0.3041 & 0.4803 & 0.0972 & 0. & 0.5337 & 0.2929 \\
\hline Madura & 0.0514 & 0.2277 & 0.2651 & 0.5072 & 0.1439 & 0.0230 & 0.6671 & 0.5667 \\
\hline Bali & 0.0689 & 0.1882 & 0.3359 & 0.4759 & 0.2465 & 0.0337 & 0.4501 & 0.2432 \\
\hline Lombok & 0.0541 & 0.1228 & 0.3772 & 0.5000 & 0.1695 & 0.0633 & 0.4741 & 0.0426 \\
\hline Sumbawa & 0.0390 & 0.1378 & 0.3389 & 0.5233 & 0.1383 & 0.0518 & 0.7197 & 0.4313 \\
\hline Sulawesi & 0.0441 & 0.1227 & 0.4430 & 0.4343 & 0.1782 & 0.0051 & 0.5203 & 0.1195 \\
\hline $\begin{array}{l}\text { The Philippines } \\
(1975)\end{array}$ & 0.0609 & 0.0783 & 0.3574 & 0.5643 & 0.1433 & 0.0160 & 0.5585 & 0.0488 \\
\hline Thailand (1972) & 0.0217 & 0.2177 & 0.2748 & 0.5074 & 0.0709 & 0.0269 & 0.6057 & 0.3310 \\
\hline Malaysia (1974) & 0.0185 & 0.1160 & 0.1560 & 0.7280 & 0.0393 & 0.0128 & 0.7449 & 0.2135 \\
\hline
\end{tabular}

Table 5. Comparison of gene frequencies in Indonesian native chicken populations (1981)

\begin{tabular}{|c|c|c|c|c|c|c|c|c|}
\hline $\begin{array}{ll} & \begin{array}{c}\text { Gene } \\
\text { frequency }\end{array} \\
\text { Locality } & \\
\end{array}$ & $\mathrm{q}_{\mathrm{I}}$ & $q_{E}$ & $\mathrm{qe}_{\mathrm{e}}+$ & $\mathrm{q}_{\mathrm{e}}$ & qs & $q_{B}$ & qId & $q_{p}$ \\
\hline $\begin{array}{l}\text { Desa Tikunama } \\
\text { Lenong (Traja) }\end{array}$ & 0.0970 & 0.1990 & 0.4939 & 0.3071 & 0.1590 & 0.0722 & 0.4460 & 0.1362 \\
\hline $\begin{array}{l}\text { Desa Labo } \\
\text { (Traja) }\end{array}$ & 0.0219 & 0.0706 & 0.7162 & 0.2132 & 0.1645 & 0 & 0.1972 & 0.0266 \\
\hline Makale (Traja) & 0.0733 & 0.1141 & 0.4650 & 0.4209 & 0.1274 & 0.0313 & 0.2632 & 0.0881 \\
\hline $\begin{array}{l}\text { Tuntungan } \\
\text { (Medan) }\end{array}$ & 0.0555 & 0.0545 & 0.3815 & 0.5640 & 0.0624 & 0.0120 & 0.8072 & 0.2834 \\
\hline $\begin{array}{l}\text { Pancur Batu } \\
\text { (Medan) }\end{array}$ & 0.0780 & 0.0298 & 0.5502 & 0.4200 & 0.0419 & 0.0204 & 0.9803 & 0.3480 \\
\hline $\begin{array}{l}\text { Baturiti } \\
\text { (Bali) }\end{array}$ & 0.1055 & 0.0925 & 0.5646 & 0.3429 & 0.3023 & 0.0925 & 0.4318 & 0.1329 \\
\hline
\end{tabular}




\section{Morphology of Indonesian Native Chicken}

The genetical analysis of external morphological characters of the native chicken has been performed for the data obtained in the 1977, 1978 and 1981 investigations on the Indonesian native livestock. A total of 5,845 yard chickens were used for analyses of their external genetic characters recorded at 11 provinces during the three investigations. Tables 4 and 5 reveal the frequencies of genes controlling the allelomorphic characters, comparing the Indonesian native chicken with the Philippine,

Table 6. Comparison of the amount of introgression (Q) of the foreign breeds: Rhode Island Red and/or New Hampshire (SR), White Leghorn (WL) and Barred Plymouth Rock (BR) into the native chicken population, and the native gene content in the present-day native chicken population $\left[1-\left(Q_{w_{2}}+Q_{B R}+Q_{S R}\right)\right]$ in Indonesia, The Philippines, Thailand and Malaysia.

\begin{tabular}{|c|c|c|c|c|}
\hline $\begin{array}{l}\quad \begin{array}{l}\text { Rates of } \\
\text { introgression }\end{array} \\
\text { Locality }\end{array}$ & $\mathrm{Q}_{\mathrm{SR}}=\mathrm{q}_{\mathrm{Id}}-\mathrm{q}_{\mathrm{B}}$ & $Q_{W L}=q_{1}$ & $\mathrm{Q}_{\mathrm{BR}}=\mathrm{q}_{\mathrm{B}}-\mathrm{q}_{\mathrm{t}}$ & $1-\left(Q_{\mathrm{WL}}+Q_{\mathrm{B}}+Q_{\mathrm{SR}}\right)$ \\
\hline \multicolumn{5}{|l|}{$\begin{array}{l}\text { Indonesia } \\
\text { Investigation in } \\
1977\end{array}$} \\
\hline Jawa Timur & 0.6556 & 0.0623 & -0.0480 & 0.2821 \\
\hline Jawa Tengah & 0.5782 & 0.0487 & -0.0395 & 0.3731 \\
\hline Jawa Barat & 0.5087 & 0.0312 & -0.0282 & 0.4601 \\
\hline Madura & 0.5005 & 0.0525 & -0.0376 & 0.4470 \\
\hline Bali & 0.3448 & 0.1025 & -0.0785 & 0.5527 \\
\hline Lombok & 0.3769 & 0.0871 & -0.0024 & 0.5360 \\
\hline \multicolumn{5}{|l|}{$\begin{array}{l}\text { Investigation in } \\
1978\end{array}$} \\
\hline Aceh & 0.5602 & 0.0239 & -0.0074 & 0.4159 \\
\hline Sumatera Barat & 0.5389 & 0.0227 & 0.0268 & 0.4116 \\
\hline Jawa Barat & 0.5231 & 0.0126 & -0.0126 & 0.4643 \\
\hline Madura & 0.6157 & 0.0514 & -0.284 & 0.3329 \\
\hline Sulawesi Selatan & 0.4762 & 0.0441 & -0.0390 & 0.4797 \\
\hline Bali & 0.3812 & 0.0689 & -0.0352 & 0.5499 \\
\hline Lombok & 0.4108 & 0.0541 & 0.0092 & 0.5259 \\
\hline Sumbawa & 0.6679 & 0.0390 & 0.0128 & 0.2803 \\
\hline \multicolumn{5}{|l|}{$\begin{array}{c}\text { Investigation in } \\
1981\end{array}$} \\
\hline $\begin{array}{l}\text { Desa Tikunama } \\
\text { Lenong(Traja) }\end{array}$ & 0.3490 & 0.0970 & -0.0248 & 0.5788 \\
\hline $\begin{array}{l}\text { Desa Labo } \\
\text { (Traja) }\end{array}$ & 0.1753 & 0.0219 & -0.0219 & 0.8247 \\
\hline Makale(Traja) & 0.1899 & 0.0733 & -0.0420 & 0.7788 \\
\hline $\begin{array}{l}\text { Tuntungan } \\
\text { (Medan) }\end{array}$ & 0.7517 & 0.0555 & -0.0435 & 0.2363 \\
\hline $\begin{array}{l}\text { Pancur Batu } \\
\text { (Medan) }\end{array}$ & 0.9023 & 0.0780 & -0.0576 & 0.0773 \\
\hline $\begin{array}{l}\text { Baturiti } \\
\text { (Bali) }\end{array}$ & 0.3263 & 0.1055 & -0.0130 & 0.5812 \\
\hline $\begin{array}{l}\text { The Philippines } \\
\text { (1975) }\end{array}$ & 0.5425 & 0.0586 & -0.0392 & 0.4415 \\
\hline Thailand (1972) & 0.5788 & 0.0217 & 0.0052 & 0.5427 \\
\hline Malaysia (1974) & 0.7264 & 0.0185 & -0.0057 & 0.2551 \\
\hline
\end{tabular}


Thai and Malaysian ${ }^{3,6,7)}$.

The values of $I, B$ and $S$ gene frequencies were very low in the Indonesian native chicken populations. On the other hand, Id gene frequency of the Indonesian was as high as those of the other Southeast Asian countries, pea-comb and $\mathrm{e}^{+}$gene frequencies were higher in the Indonesian than in the other countries. Concerning the pea-comb frequency, the values in Bali, Lombok and Sulawesi were low, but the native chicken populations in Jawa and Madura showed higher frequencies:

The admixture $(Q)$ of these improved breeds and the native gene content in the present-day native chicken populations were calculated based on the gene constitutions of three improved breeds expressed by ; II EE SS BB IdId pp for White Leghorn (WL), ii ee ss bb IdId pp for Rhode Island Red (SR) and II EE SS BB IdId pp for Barred Plymouth Rock (BR) as shown in Table 6.

The values of the amount of introgression of White Leghorn and Barred Plymouth Rock were very low or almost negligible, while the value of Rhode Island Red was very high. The results also indicate that the general yard chicken populations in Indonesia except East Jawa, Madura, Sumbawa and Sumatra hold about 50\% native genes on the

Table 7. Comparison of gene frequencies in native chicken populations which are not attributable to the inflow from European improved breeds $\left(\mathrm{q}^{(N)}\right)$ :

Rhode Island Red and/or New Hampshire(SR), White Leghorn(SL) and Barred Plymouth Rock(BR)

\begin{tabular}{|c|c|c|c|c|c|c|c|c|}
\hline $\begin{array}{l}\text { Rate of } \\
\text { introgression } \\
\text { Locality }\end{array}$ & $\begin{array}{l}\mathrm{qE}^{(\mathrm{N})} \\
=\frac{\mathrm{qE}-}{\mathrm{qB}}\end{array}$ & $\begin{array}{l}\mathrm{qe}^{+(\mathrm{N})} \\
=\mathrm{qe}^{+}\end{array}$ & $\begin{array}{l}q e^{(N)}= \\
q e-Q_{s R}\end{array}$ & $\begin{array}{l}\mathrm{qS}^{(N)}= \\
\mathrm{qS}- \\
\mathrm{qB}\end{array}$ & $\begin{array}{l}q s^{(N)}= \\
q s^{-} \\
Q_{s R}\end{array}$ & $\begin{array}{l}\text { qid }^{(N)} \\
= \\
\text { qid }\end{array}$ & $\begin{array}{l}q p^{(N)}= \\
q p-q I d\end{array}$ & $\mathrm{qP}^{\mathrm{P}^{(N)}}=$ \\
\hline \multicolumn{9}{|l|}{$\begin{array}{l}\text { Indonesia } \\
\text { Investigation in } \\
1977\end{array}$} \\
\hline Jawa Timur & 0.2339 & 0.3371 & -0.2409 & 0.0484 & 0.2817 & 0.2821 & -0.3280 & 0.6101 \\
\hline Jawa Tengah & 0.2070 & 0.3330 & -0.1274 & 0.0822 & 0.3304 & 0.3731 & -0.2834 & 0.6565 \\
\hline Jawa Barat & 0.3132 & 0.3176 & -0.1425 & 0.1421 & 0.3462 & 0.4601 & -0.2424 & 0.7025 \\
\hline Madura & 0.2599 & 0.3665 & -0.1418 & 0.0873 & 0.3973 & 0.4470 & -0.1089 & 0.5559 \\
\hline Bali & 0.1332 & 0.4033 & -0.0947 & 0.2562 & 0.3750 & 0.5527 & 0.4005 & 0.1522 \\
\hline $\begin{array}{l}\text { Lombok } \\
\text { Investiagation in } \\
1978\end{array}$ & 0.0255 & 0.5671 & -0.0542 & 0.2047 & 0.3337 & 0.5360 & 0.4552 & 0.0808 \\
\hline Aceh & 0.0947 & 0.3571 & -0.0285 & 0.1403 & 0.2830 & 0.4159 & -0.1091 & 0.5250 \\
\hline Sumatra Barat & 0.0841 & 0.3454 & -0.0179 & 0.0950 & 0.3166 & 0.4116 & 0.0735 & 0.3381 \\
\hline Jawa Barat & 0.2156 & 0.3041 & -0.0428 & 0.0972 & 0.3797 & 0.4643 & 0.1714 & 0.2929 \\
\hline Madura & 0.2047 & 0.2651 & -0.1085 & 0.1209 & 0.2404 & 0.3329 & -0.2338 & 0.5667 \\
\hline Sulawesi Selatan & 0.1176 & 0.4430 & -0.0419 & 0.1731 & 0.3466 & 0.4797 & 0.3602 & 0.1195 \\
\hline Bali & 0.1545 & 0.3359 & 0.0947 & 0.2128 & 0.3723 & 0.5499 & 0.3067 & 0.2432 \\
\hline Lombok & 0.0595 & 0.3772 & 0.0892 & 0.1062 & 0.4197 & 0.5259 & 0.4833 & 0.0426 \\
\hline Sumbawa & 0.0860 & 0.3389 & -0.1446 & 0.0865 & 0.1938 & 0.2803 & -0.1510 & 0.4313 \\
\hline $\begin{array}{c}\text { The Philippines } \\
\text { (1975) }\end{array}$ & 0.0449 & 0.3574 & 0.0218 & 0.1273 & 0.3142 & 0.4415 & 0.3927 & 0.0488 \\
\hline Thailand (1972) & 0.3177 & 0.2247 & 0.0021 & 0.0781 & 0.4664 & 0.5427 & 0.1168 & 0.4529 \\
\hline Malaysia (1974) & 0.1032 & 0.1560 & 0.0016 & 0.0265 & 0.2343 & 0.2551 & 0.0416 & 0.2135 \\
\hline
\end{tabular}


Table 8. Comparison of gene frequencies in native chicken populations which are not attributable to the inflow from European improved breeds $\left(q^{(N)}\right)$ :

Rhode Island Red and/or New Hampshire(SR), White Leghorn(WL) and Barred Plymouth Rock(BR)

\begin{tabular}{|c|c|c|c|c|c|c|c|c|c|}
\hline \multicolumn{2}{|c|}{$\begin{array}{l}\text { Rate of } \\
\text { introgression } \\
\text { Locality }\end{array}$} & $\begin{array}{l}\mathrm{q} E^{(N)}= \\
q E^{-} \\
q B\end{array}$ & $\begin{array}{l}\mathrm{qe}^{+(N)} \\
=\mathrm{qe}^{+}\end{array}$ & $\begin{array}{l}q e^{(N)}= \\
q e-Q_{s R}\end{array}$ & $\begin{array}{l}q S^{(N)}= \\
q S^{-} \\
q B\end{array}$ & $\begin{array}{l}\mathrm{qS}^{(\mathrm{N})}= \\
\mathrm{qs}- \\
\mathrm{QSR}^{-}\end{array}$ & $\begin{array}{l}\text { qid }^{(N)} \\
=\text { qid }^{-}\end{array}$ & $\begin{array}{l}\mathrm{qp}^{(\mathrm{N})}= \\
\mathrm{qp}-\mathrm{qId}\end{array}$ & ${ }_{\mathrm{qP}}^{\mathrm{qP}}=$ \\
\hline \multicolumn{10}{|c|}{$\begin{array}{l}\text { Indonesia } \\
\text { Investigation in } \\
1981\end{array}$} \\
\hline & $\begin{array}{l}\text { Desa Tikunama } \\
\text { Lenong(Traja) }\end{array}$ & 0.1268 & 0.4939 & -0.0419 & 0.0868 & 0.4920 & 0.5540 & 0.4178 & 0.1362 \\
\hline (2) & $\begin{array}{l}\text { Desa Labo } \\
\text { (Traja) }\end{array}$ & 0.0706 & 0.7162 & 0.0379 & 0.1645 & 0.6602 & 0.8028 & 0.7762 & 0.0266 \\
\hline (3) & Makale(Traja) & 0.0828 & 0.4650 & 0.2310 & 0.0961 & 0.6827 & 0.7368 & 0.6487 & 0.0881 \\
\hline (4) & $\begin{array}{l}\text { Tuntu } \\
\text { (Mede }\end{array}$ & 0.0425 & 0.3815 & -0.1877 & 0.0504 & 0.1859 & 0.4928 & -0.0906 & 0.2834 \\
\hline (5) & $\begin{array}{l}\text { Pancur Batu } \\
\text { (Medan) }\end{array}$ & 0.0094 & 0.5502 & -1.7700 & 0.0215 & 0.0558 & 0.0197 & -0.3283 & 0.3480 \\
\hline (6) & $\begin{array}{l}\text { Baturiti } \\
\text { (Bali) }\end{array}$ & 0 & 0.5646 & -0.31650 & 0.2098 & 0.3714 & 0.5682 & 0.4353 & 0.1329 \\
\hline
\end{tabular}

average.

The frequencies in the Indonesian native chicken populations not attributable to the inflow from European improved breeds were calculated to be compared with those in the Philippine, Thai and Malaysian chickens (Table 7 and 8). Their frequencies of $e^{+}, s$ and id genes were as high as those of the Philippine, Thai and Malaysian native chicken populations. Concerning the frequency of $\mathrm{P}$ gene, the value for the Indonesian was also as high as those for the native chicken other than the Philippine.

\section{Discussion}

1. Body measurement of Indonesian native chickens

In the 1977, 1978 and 1981 investigations for the Indonesian native livestock, 212 Indonesian native chickens were used for the measurements of 8 different body parts and the body weight. These results were compared with those of the Philippine and Malaysian native chickens. According to our previous reports on the Malaysian and Philippine native chickens ${ }^{3,7)}$, they were divided into four body types - a small and slender non-game type, a small and slender game type, a large and heavy non-game type, and a large and heavy game type.

There were no differences in these body types of the Indonesian native chicken except the large and heavy game type imported from Thailand.

The principal component analysis has been applied to the craniometry and the body measurement. HAYASHI et al. ${ }^{11)}$ and NishidA et al. ${ }^{12)}$ classified the characteristics of the skull of the Indonesian and Korean native cattle using this method. Applying this analytical method to the avian craniometry and body measurement, HAYASHI et al. ${ }^{13}$ divided the jungle fowl and the Japanese native breeds of domestic fowl into a small-, a middle- and a large-sized group based on the discrimination afforded by the size 
vector. NISHIDA et $a l{ }^{2)}$ recently carried out the analysis of the body measurement for the Korean native fowl, and confirmed the possibility of its effectiveness on the morphological studies for the characterization of the different native chicken breeds.

In the body measurement of the Korean native chicken ${ }^{2)}$ the first principal component accounted for $79.7 \%$ of all variations and the second component for $12.8 \%$. In the present study, the first principal component accounted for $80.6 \%$ and the second component for $10.7 \%$. In both cases, the sum of the first and second components reached more than $90 \%$. This result indicates that the principal component analysis is applicable to the measurement as a suitable morphometric method.

The lengths of wing and three long bones and the height of comb were applicable to the discrimination of the size of chicken body conformation, since eigenvectors of these 5 variables were larger than those of the other variables in the first principal component. The lengths of long bones of the hind limb as well as the length of wing appeared to be significant factors for the avian body conformation. The height of comb and the lengths of wing and two long bones were adopted as a discriminator of the shape in the second principal component. The lengths of wing and long bones seem to be more effective to the discrimination of the size and shape in the chicken body conformation, since the size of comb is controlled by the hormonal activity as one of the secondary sexual characters.

2. Morphological genetic characters of Indonesian native chickens

The chicken population in Indonesia is still mainly composed of the mongrel population of native chicken as mentioned above. These indigenous breeds except only two local breeds-Ayam Kedu and Ayam Mutioar-expressed the various external genetic characters. The incidence of these morphological characters of native chicken controlled by known major genes was counted in the individual villages or communities. Most of these marker genes were selected from the genes controlling the allelomorphic characters of domestic fowl-feather color, plumage pattern and shank color as shown in Tables 4 and 5. Since the pattern of their phenotypic expression was clarified by the comprehensive works of HUTT $^{13)}$ and KIMBALL ${ }^{14,15)}$, the existence of these genes was exactly judged and recorded.

According to the comparison of gene frequencies in the Indonesian, Philippine, Thai and Malaysian native chickens, I and B alleles originally seem to have never been involved in the Indonesian native chicken as well as those of the other Southeast Asian countries. The value of $\mathrm{e}^{+}$gene frequency in the Indonesian native chicken was similar to that of the Philippine, but rather higher than those of the Thai and Malaysian. On the other hand, the value of pea-comb gene frequency in the Philippine native chicken was very low. Therefore, the low values of $I$ and $B$ gene frequencies and the high values of pea-comb (P) and $\mathrm{e}^{+}$gene frequencies appear to represent the distinctive external genetic characters of the Indonesian native chicken.

Many improved European breeds such as Australorp, New Hampshire, White Cornish, Rhode Island Red, White Leghorn and Barred Plymouth Rock have been introduced into Indonesia. Of these breeds, the last three are considered to be the 
main breeds introduced into Southeast Asian countries from Europe and USA ${ }^{16-18)}$. The values of the amount of introgression of White Leghorn and Barred Plymouth Rock were almost negligible, while that of Rhode Island Red was very high.

The native gene content in the present-day native chicken populations in Indonesia can be estimated as shown in Table 6 . The result indicates that the Indonesian yard chicken still holds about $50 \%$ native genes on the average. This value appears to be almost the same as those of the Thai and Philippine yard chicken ${ }^{6,7)}$.

From the results of the calculation of gene frequencies in the Indonesian native chicken population not attributable to the inflow from European improved breeds (Tables 7 and 8 ), it is assumed that the Indonesian native chicken might originally have possessed the wild plumage pattern $\left(\mathrm{e}^{+}\right)$, the gold feather color $(\mathrm{s})$, the black shank (id) and the pea-comb (P).

\section{Acknowledgments}

The authors wish to thank the provincial officers and farmers in the regions we visited for their kind cooperation. We are indebted to the members of the Faculty of Animal Science, Bogor Agricultural University for their valuable arrangement and cooperation in the field investigation. The authors also express hearty thanks to the members of the Society for Researches on Native Livestock for their kind assistance. This work was supported by Grant-in-Aid for Overseas Scientific Survey No. 304115 and No. 57043031 from Ministry of Education, Science and Culture, Japan.

\section{References}

1) Hayashi, Y., T. Nishida, T. Fujioka, I. Tsugiyama, K. Mochizuki and $M$. Tомімото, Jpn. J. Vet. Sci., $44:$ 103-106. 1982.

2) Nishida, T., C.-S. Lee, Y. Hayashi, T. Hashiguchi and K. Mochizuki, Jpn. J. Vet. Sci, $45: 179-186$.

3) Nishida, T., K. Nozawa and T.I. Azmi, Rep. Soc. Res. Native Livestock, $7: 44-52$. 1976.

4) Nishida, T., K. Nozawa, K. Kondo, S.S. Mansjoer and H. Martojo, in The Origin and Phylogeny of Indonesian Native Livestock. 47-70. The Research Group of Overseas Scientific Survey,

5) Nishida, T. and J.S. Masangkay, Rep. Soc. Res. Native Livestock, 8: 93-105. 1978.

6) Nishida, T., K. Nozawa, Y. Fujio, S. Watanabe and J. Nishida, Rep. Soc. Res. Native Livestock, 6 : 144-159. 1974.

7) Nishida, T., K. Nozawa, T. Hashiguchi, T. Namikawa and J. Nishida, Rep. Soc. Res. Native Livestock, $8: 104-114$.

8) Biro Pusat Statistik, Statistical Pocketbook of Indonesia. 172-175. Biro Pusat Statistik. Jakarta.

9) Ball, S.C., Bernice P. Bishop Mus. Bull., 108:1-121. 1933.

10) Baldwin, S.P., H.C. Oberholser and L.G. Worley, Sci. Pub. Cleaveland Mus. Nat. Hist., 2 : 1-165. 1931.

11) Hayashi, Y., T. Nishida, K. Mochizuki and J. Otsuka, Jpn. J. Vet. Sci., 43 : 901907. 1981.

12) Nishida, T., Y. Hayashi, C.-S. LeE, Y.J. Cho, T. Hashiguchi and K. Mochizuki, Jpn. J. Vet. Sci., $45:$ 537-541. 1983.

13) Hutr, F.B., Genetics of the Fowl. 81-226. McGraw-Hill. New York. 1949. 
14) Kimball, E., Poult. Sci., 31 : 73-79. 1952 a.

15) Kimball, E., J. Hered,, 43 : 129-132. 1952 b.

16) Allarey, V.F., Philip. Agric. Forest., 2 : 49-55. 1912.

17) Fronda, F.M., Proc. 9th Pacific Sci. Congr., 2: 186-191. 1960.

18) Vajok-KasikiJ, L.S., Proc. 9th. Pacific Sci. Congr, 2 : 183-185. 1960.

\title{
インドネシア在来鶏の形態学的研究
}

\author{
西田隆雄・林 良博 ・ 野沢 謙* ・橋口 勉** \\ Sri Supraptini MANSJOER ${ }^{* * *}$ \\ 東京大学農学部, 東京都文京区 113 \\ *京都大学霊長類研究所, 犬山市 484 \\ ** 鹿児島大学農学部, 鹿児島市 890 \\ ***ボゴール農科大学
}

\begin{abstract}
1977 年, 1978 年および 1981 年に行なわれたインドネ シア在来家畜調查において，雄 164 羽と雌 48 羽, 計 212 羽の在来鵎の生体計測を行ない，その計測値を主成分分 析法によって検討した。 その結果, 以下のことが明らか にされた．1）䦢鷄種を除くと、インドネシア在来鵎の 各集団間には，体の大きさおよび体型の差が認められな い，2）マドゥラの闘鶏種の雄およびバンコックと呼ば れる南スラウェシの闘鷄の雄は, 第一主成分では最も大 型の群机を形成する， 5,845 羽の在来鵎について，外皮
\end{abstract}

に属する形態学的形質を記録し，統計遺伝学的万法に よって，形態学的形質の発現を制御している迪伝子の頻 度 $(q)$, 改良種の侵入率 $(Q)$, 残存する在来遺伀子量 および改良種からの流入では説明出来ない遗伝子頻度 $\left(q^{(\mathrm{N})}\right)$ を求めた。 その結果，インドネシア在来鵎は， 約 $50 \%$ の在来遗伝子を保持していることが明らかにさ れた。

日畜会報, $59(12): 1047-1058,1988$. 